\title{
AKTIVITAS SISWA DALAM PEMBELAJARAN MATEMATIKA DENGAN MENGGUNAKAN PENDEKATAN SCIENTIFIC
}

\author{
Wahyuni $^{1}$, M.Ikhsan $^{2}$, Bahrun $^{3}$ \\ ${ }^{1}$ Universitas Syiah Kuala, Jl. Tgk. Chik Pante Kulu, Banda Aceh 23111, Indonesia \\ ${ }^{2}$ Universitas Syiah Kuala, Jl. Tgk. Chik Pante Kulu, Banda Aceh 23111, Indonesia \\ ${ }^{3}$ Universitas Syiah Kuala, J1. Tgk. Chik Pante Kulu, Banda Aceh 23111, Indonesia \\ Email: ayuni2009pma@gmail.com \\ Email: ikhsan@unsyiah.ac.id \\ Email: bahrun1959@gmail.com
}

\begin{abstract}
Abstrak
Pemerintah telah memberlakukan Kurikulum 2013 sebagai upaya untuk mencapai tujuan pendidikan nasional yang sesuai dengan perkembangan zaman dan memiliki ciri khas dalam penggunaan pendekatan scientific/ilmiah pada proses pembelajarannya. Tidak mudah untuk menerapkan pendekatan scientific dengan baik dan benar khususnya pada mata pelajaran matematika. Banyak aspek yang menjadi ukuran keberhasilan penerapan tersebut salah satunya aktivitas siswa dalam proses pembelajaran. Tujuan penelitian ini untuk mendeskripsikan aktivitas siswa dalam pembelajaran matematika menggunakan pendekatan scientific dengan subjek siswa kelas XI SMA Labschool yang ditentukan berdasarkan kategori tinggi, sedang dan rendah. Data dalam penelitian ini diperoleh dari hasil observasi terhadap kegiatan siswa dalam proses pembelajaran dan hasil wawancara yang selanjutnya dianalisis secara deskriptif melalui tahap reduksi data, penyajian data, dan penarikan kesimpulan. Hasil penelitian menunjukkan bahwa untuk ketiga subjek komponen yang belum terlaksana dengan baik adalah mengkomunikasikan. Aktivitas yang berlangsung hanya sebatas berdiskusi dengan teman sekelompok, sedangkan mengkomunikasikan yang dituntut dalam pendekatan scientific memiliki beberapa kegiatan yang harus di laksanakan. Hal itu terjadi karena beberapa faktor diantaranya waktu yang tersedia tidak cukup untuk melaksanakan kegiatan tersebut sehingga terlewatkan.. Ketiga subjek memiliki aktivitas yang berbeda dalam setiap kegiatan dan belum seluruhnya sesuai dengan deskripsi yang diharapkan dalam pendekatan scientific.
\end{abstract}

Kata Kunci: Aktivitas Siswa, Pendekatan Scientific, Pembelajaran Matematika.

\section{Abstract}

The Government has enacted the 2013 Curriculum as an effort to achieve national education goals that are in line with the times and have characteristics in the use of scientific/scientific approaches to the learning process. It is not easy to apply the scientific approach properly and correctly, especially in mathematics. Many aspects that become a measure of the success of the application is one of the activities of students in the learning process. The purpose of this study is to describe the activities of students in mathematics learning using a scientific approach with subjects of class XI Labschool High School determined by high, medium and low categories. The data in this study were obtained from observations of student activities in the learning process and the results of interviews which were then analyzed descriptively through the stages of data reduction, data presentation, and conclusion drawing. The results of the study show that for the three component subjects that have not been implemented properly is communicating. Activities that take place are limited to discussing with group friends, while communicating the demands in the scientific approach has several activities that must be carried out. This happens because several factors including the time available is not enough to carry out these activities so that they are missed. The three subjects have different activities in each activity and have not all been in accordance with the description expected in the scientific approach.

Keywords: Students'Activity, Scientific Approach, Mathematics Learning.

\section{PENDAHULUAN}

Seiring berkembangnya ilmu pengetahuan dan teknologi, maka perlu dikembangkan pula kualitas dan mutu pendidikan. Salah satu alternatif yang dilakukan adalah dengan melakukan 
perubahan kurikulum (Rusindrayanti, 2015). Kurikulum Indonesia sendiri telah mengalami beberapa kali perubahan. Perubahan kurikulum yang terbaru dilakukan pada tahun 2013, perubahan ini merupakan suatu bentuk penyempurnaan dari Kurikulum Tingkat Satuan Pendidikan (KTSP) menjadi kurikulum 2013.

Kurikulum 2013 dikembangkan dengan berbagai alasan (Kemdikbud, 2013). Alasan-alasan tersebut antara lain menyangkut tantangan dan kompetensi yang dibutuhkan di masa depan. Hal yang terkait dengan kompetensi yang dibutuhkan di masa depan, dikemukakan bahwa di masa yang akan datang kompetensi yang dibutuhkan diantaranya kemampuan berkomunikasi dan kemampuan berpikir jernih dan kritis. Sehubungan dengan kemampuan tersebut, di samping dilakukan pengembangan dan penataan ulang standar kompetensi serta kompetensi dasar dari kurikulum sebelumnya, proses pembelajaran untuk mencapai kompetensinya pun dilakukan penyesuaian. Kurikulum 2013 mulai diimplementasikan pada tahun ajaran 2014/2015. Salah satu alasan pemerintah mengembangkan kurikulum 2013 adalah semangat perubahan proses pembelajaran dan proses penilaian (Prasetio, 2015).

Kurikulum 2013 menganut pandangan dasar bahwa pengetahuan tidak dapat dipindahkan begitu saja dari guru ke peserta didik. Peserta didik adalah subjek yang memiliki kemampuan untuk secara aktif mencari, mengolah, mengkonstruksi, dan menggunakan pengetahuan. Untuk itu pembelajaran harus berkenaan dengan kesempatan yang diberikan kepada peserta didik untuk mengkonstruksi pengetahuan dalam proses kognitifnya. Agar benar-benar memahami dan dapat menerapkan pengetahuan, peserta didik perlu didorong untuk bekerja memecahkan masalah, menemukan segala sesuatu untuk dirinya, dan berupaya keras mewujudkan ide-idenya (Permendikbud No 81 a tahun 2013).

Kurikulum 2013 menggunakan sebuah konsep pendekatan ilmiah (scientific). Pendekatan saintifik merupakan proses pembelajaran yang menggunakan proses berpikir ilmiah. Pendekatan ilmiah dapat dijadikan sebagai jembatan untuk perkembangan dan pengembangan sikap, keterampilan dan pengetahuan peserta didik. Upaya penerapan pendekatan saintifik/ilmiah dalam proses pembelajaran sering disebut-sebut sebagai ciri khas dan menjadi kekuatan tersendiri dari keberadaan Kurikulum 2013 (Hosnan, 2014).

Dalam implementasi dilapangan guru dituntut untuk melaksanakan proses pembelajaran yang mengembangkan lima pengalaman belajar pokok yaitu adalah mengamati, menanya, mengumpulkan informasi, mengasosiasikan/menalar dan mengkomunikasikan (Kemendikbud, 2013). Ke-5 komponen tersebut sering disingkat dengan komponen $5 \mathrm{M}$ dan harus dilaksanakan pada semua mata pelajaran. Untuk mata pelajaran matematika, materi, atau situasi tertentu, sangat mungkin pendekatan ilmiah ini tidak selalu tepat diaplikasikan secara prosedural (Rusindrayanti, 2015).

Berdasarkan data awal yang di kumpulkan, peneliti menemukan bahwa masih ada komponen $5 \mathrm{M}$ yang belum muncul selama proses pembelajaran berlangsung, menurut guru yang mengajar hal tersebut sering terjadi dikarenakan memang tipe anak yang berada dikelas tersebut tidak terlalu aktif 
dalam hal berkomunikasi, tetapi mereka lebih aktif dalam hal melakukan (Observasi dan wawancara, 2017). Hal ini juga didukung dengan hasil penelitian yang mengatakan bahwa masih banyak terdapat masalah dalam pelaksanaan pembelajaran matematika dengan menggunakan pendekatan saintifik. Salah satunya adalah penelitian yang dilakukan oleh Prasetyo (2015) yang mengatakan bahwa masih terdapat banyak masalah berkaitan dengan implementasi kurikulum 2013 khususnya dalam pembelajaran matematika. Keberhasilan kurikulum tergantung sejauh mana implementasinya disekolah. Beberapa pengalaman sebelumnya perubahan kurikulum tidak mengubah proses pembelajaran di kelas. Selain itu informasi mengenai pembelajaran yang berorientasi ilmiah masih terbatas (Surachman, 2014).

Berdasarkan penjelasan di atas, sejalan dengan berlakunya kurikulum 2013 maka sangat menarik untuk dilakukan penelitian mengenai sejauh mana implementasi kurikulum 2013 di sekolah khususnya dalam melaksanakan lima pokok pengalaman belajar yang harus muncul dalam pembelajaran. Dalam tulisan ini hanya difokuskan pada deskripsi kegiatan siswa pada saat proses pembelajaran, sehingga yang menjadi rumusan masalah dalam penelitian ini adalah komponen apasaja yang telah muncul dalam proses pembelajaran matematika dengan menggunakan pendekatan scientific?

\section{METODE PENELITIAN}

Pendekatan yang digunakan dalam penelitian ini adalah pendekatan kualitatif, dengan jenis penelitian deskriptif. Peneliti mengamati, kemudian mengkaji dan menganalisis deskripsi kegiatan yang dilakukan siswa selama proses pembelajaran berlangsung. Setelah data terkumpul, selanjutnya peneliti memaparkan apa yang terjadi dalam bentuk laporan penelitian seperti apa adanya. Penelitian ini dilakukan selama dua kali pertemuan dengan subjek penelitiannya adalah 3 siswa kelas XI Labscool Unsyiah, alasan peneliti mengambil 3 subjek dikarenakan sesuai jenis penelitian kualitatif yang melakukan penelitian secara mendalam dan fokus pada tujuan penelitian maka diambil 3 subjek yang mewakili setiap kemampuan serta keterbatasan waktu penelitian. Kriteria pemilihan subjek penelitian dipilih berdasarkan nilai rapor siswa untuk pelajaran matematika dalam satu semester kebelakang dan juga atas pertimbangan dari guru bidang studi matematika. Siswa digolongkan dalam 3 kelompok. Setiap kelompok diambil masing-masing satu sebagai subjek. Penggolongan itu dibagi menjadi 3 yaitu siswa berkemampuan tinggi, siswa berkemampuan sedang dan siswa berkemampuan rendah.

Instrumen utama dalam penelitian ini adalah peneliti sendiri serta menggunakan instrumen pendukung diantaranya lembar observasi guru dan siswa dalam pembelajaran matematika dengan pendekatan scientific dan pedoman wawancara. Data dikumpulkan melalui observasi selama proses pembelajaran berlangsung dan wawancara dilakukan setelah proses pembelajaran selesai, dengan menggunakan alat bantu audio visual berupa kamera digital. Peneliti menganalisis rekaman video berkaitan dengan deskripsi kegiatan yang dilakukan siswa selama proses pembelajaran berlangsung. 


\section{HASIL PENELITIAN DAN PEMBAHASAN}

Deskripsi kegiatan siswa untuk ketiga subjek dalam komponen mengamati dapat dijelaskan sebagai berikut. Komponen mengamati untuk subjek tinggi diantaranya mendengarkan penjelasan guru tentang materi sebelumnya yaitu mengenai ellips serta penjelasan apa yang akan dipelajari selanjutnya, mengamati gambar hiperbola melalui tayangan LCD. Jadi deskripsi kegiatan yang muncul untuk subjek tinggi adalah mendengarkan dan melihat. Sedangkan untuk subjek sedang memperhatikan guru menjelaskan, membaca LKPD dan menemukan kesalahan sehingga deskripsi yang muncul untuk subjek sedang adalah membaca dan mendengar. Materi yang sedang dipelajari pada saat itu adalah tentang hiperbola dan subjek rendah memperhatikan penjelasan guru tentang hiperbola serta melihat dan membaca buku paket untuk mencari informasi tentang hiperbola. Jadi deskripsi kegiatan yang muncul untuk subjek rendah adalah membaca, menyimak dan melihat.

Deskripsi kegiatan untuk komponen pertama dari setiap subjek sudah muncul dan terlaksana dalam pembelajaran materi hiperbola dengan deskripsi yaitu membaca, mendengar, menyimak dan melihat. Untuk ketiga subjek pada awal pembelajaran sudah memunculkan komponen mengamati dengan mendengar dan menyimak penjelasan dari guru tentang pelajaran sebelumnya yaitu elips dan pelajaran yang akan dipelajari yaitu hiperbola. Setelah itu subjek melihat ataupun menonton tayangan gambar pada layar infokus menyangkut tentang sketsa gambar hiperbola. Hal ini sejalan dengan penelitian yang dilakukan oleh Dewi (2016) mengatakan bahwa tahapan mengamati biasanya digunakan sebagai apersepsi pembelajaran sebagai jalan memperoleh pengetahuan menggunakan semua indera untuk mengetahui karakteristik objek ataupun materi yang diberikan oleh guru.

Komponen kedua yaitu menanya, subjek tinggi bertanya tentang hal yang kurang dipahami, bertanya untuk mengkonfirmasi hal yang didapat, menanyakan tentang hubungan titik puncak dengan titik yang lain dan bertanya untuk mendapatkan informasi tambahan. Jadi deskripsi kegiatan yang muncul adalah membuat dan mengajukan pertanyaan, berdiskusi tentang hal yang belum dipahami, informasi tambahan yang ingin diketahui dan sebagai klarifikasi. Subjek sedang banyak bertanya mengenai hal yang kurang dimengerti, kemudian bertanya untuk mengkonfirmasi hal yang keliru mengenai tanda dalam operasi. Jadi deskripsi kegiatan yang muncul adalah membuat dan mengajukan pertanyaan, berdiskusi tentang hal yang belum dipahami dan sebagai klarifikasi. Sedangkan untuk subjek rendah bertanya setelah mencari informasi dan bertanya untuk mengkonfirmasi pernyataan yang telah dibuat. Jadi deskripsi kegiatan yang muncul adalah membuat dan mengajukan pertanyaan, dan sebagai klarifikasi.

Dari penjelasan di atas untuk komponen kedua ini sudah berjalan semestinya. Kegiatan yang muncul untuk ketiga subjek sudah termasuk dalam deskripsi kegiatan dalam komponen menanya yaitu membuat dan mengajukan pertanyaan, tanya jawab, berdiskusi tentang informasi yang belum dipahami, informasi tambahan yang ingin diketahui, atau sebagai klarifikasi (Permendikbud Nomor 
103 Tahun 2014). Namun tentunya masih ada kekurangan yang harus diperbaiki dalam komponen kedua ini. Seperti tuntunan dalam K-13 untuk komponen menanya yaitu jenis, kualitas, dan jumlah pertanyaan yang diajukan siswa (pertanyaan faktual, konseptual, prosedural, dan hipotetik). Kriteria pertanyaan yang baik adalah singkat dan jelas, menginspirasi jawaban, memiliki fokus, bersifat probing atau divergen, bersifat validatif atau penguatan, memberi kesempatan siswa untuk berpikir ulang, merangsang peningkatan tuntutan kemampuan kognitif, merangsang proses interaksi. Komponen ketiga yaitu mencari informasi/mengumpulkan informasi, subjek tinggi mencari informasi dari buku catatan, mengumpulkan informasi melalui petunjuk yang tersedia seperti pada saat menentukan titik pucak dari hiperbola, mengumpulkan informasi untuk mencari persamaan asimtot, namun keliru. Jadi deskripsi kegiatan yang muncul adalah mengeksplorasi dan mencoba. Sedangkan untuk subjek sedang mencari informasi dengan bertanya kepada teman mengenai penyelesaian soal dalam LKPD, jadi deskripsi kegiatan yang muncul adalah mencoba dan berdiskusi. Subjek rendah mencari informasi dari buku paket dengan menemukan titik P pada hiperbola, mencoba menemukan koordinat titik F', menemukan informasi mengenai asimtot yang ditanyakan kawannya namun keliru, menemukan solusi dari pertanyaan teman sekelompoknya mengenai bentuk dari hiperbola dan mencari informasi dengan mengaitkan dengan materi sebelumnya. Jadi deskripsi kegiatan yang muncul adalah mencoba dan berdiskusi.

Secara umum kesimpulan kegiatan setiap subjek untuk komponen ketiga ini adalah mengekspolasi, mencoba dan berdiskusi. Kegiatan ini masih terbatas pada pencarian informasi melalui buku teks. Hal ini tidak sesuai dengan salah satu deskripsi kegiatan untuk komponen mengumpulkan informasi/mencoba yang diharapkan dalam pendekatan scientific yaitu membaca sumber lain selain buku teks (Permendikbud No 103 Tahun 2014). Meskipun demikian guru telah berusaha agar kegiatan untuk komponen ketiga ini berjalan dengan lancar. Dewi (2016) menyebutkan bahwa aktivitas mencoba atau melakukan penyelidikan dapat dilakukan melalui penyelesaian proyekproyek kelompok, kegiatan diskusi, untuk mengembangkan rasa bagaimana belajar penyelidikan secara langsung. Pada saat yang sama, mereka mampu belajar konten yang diperlukan dengan bimbingan guru.

Komponen selanjutnya yaitu mengolah informasi atau menalar, subjek tinggi mengolah informasi untuk menemukan persamaan hiperbola melalui rumus yang telah di ketahui, mengolah informasi yang sudah dimiliki melalui titik fokus untuk menentukan nilai c, dan mengolah informasi dengan menghubungkan pengetahuan yang dimiliki tentang bentuk akar. Jadi deskripsi kegiatan yang muncul adalah mengolah informasi yang sudah dikumpulkan dan menghubungkan informasi terkait dalam rangka menemukan suatu pola. Subjek sedang menemukan informasi dan mengaplikasikannya dengan mengoperasikan dalam bentuk aljabarnya serta bertanya kepada teman kelompok lain, jadi deskripsi kegiatan yang muncul adalah mengolah informasi yang sudah dikumpulkan. Sedangkan untuk subjek rendah pada komponen keempat ini tidak muncul. 
Kesimpulan untuk komponen keempat ini hanya subjek tinggi dan sedang yang melakukan komponen mengolah informasi dengan deskripsi kegiatan mengolah informasi yang sudah dikumpulkan dan menghubungkan informasi terkait dalam rangka menemukan suatu pola. Subjek melakukan kegiatan ini dengan mengolah informasi dari hasil pengerjaan LKPD dan juga informasi yang didapat sebelumnya. Hal ini sesuai dengan deskripsi kegiatan yang diharapkan untuk komponen mengolah informasi ini yaitu salah satunya mengolah informasi yang sudah dikumpulkan baik terbatas dari hasil kegiatan mengumpulkan/eksperimen mau pun hasil dari kegiatan mengamati dan kegiatan mengumpulkan informasi (Permendikbud No 81 a). Hal ini berbeda dengan penelitian yang dilakukan oleh surachman (2014) yang menyebutkan dalam kegiatan menalar atau mengolah informasi sebagian besar MA Kotamadya Yogyakarta masih terbatas untuk memasukkan informasi kedalam tabel, mencari contoh lain atau menjawab pertanyaan/soal guru. Hal ini tidak sesuai dengan tuntutan kurikulum, karena yang dituntut oleh kurikulum adalah kegiatan menalar merupakan kegiatan untuk memunculkan pola-pola pikir siswa dari berbagai informasi yang dikumpulkan.

Komponen yang terakhir adalah mengkomunikasikan, secara umum kegiatan mengkomunikasikan dalam pembelajaran hiperbola ini hanya sebatas berdiskusi dengan teman. Tidak ada presentasi maupun penyampaian hasil kerja secara keseluruhan dari mengamati sampai dengan menalar. Padahal presentasi itu sangat penting untuk mengetahui pengetahuan siswa yang diperoleh. Jika hanya sebatas berdiskusi bersama teman dikhawatirkan pengetahuan yang diperoleh tidak secara menyeluruh hanya sebagian saja. Padahal, untuk mengkomunikasikan ini bentuk hasil belajar yang harus muncul adalah menyajikan hasil kajian (dari mengamati sampai menalar) dalam bentuk tulisan, grafis, media elektronik, multimedia dan lain-lain (permendikbud No 103 Tahun 2014). Seperti dalam peneltitan Dewi (2016) yang mengatakan bahwa salah satu kegiatan mengkomunikasikan dalam tahapan penelitiannya adalah $S L C$ dan review, semua dilakukan secara baik oleh peserta didik dengan bimbingan guru. Aktivitas mengkomunikasikan mulai dari yang sederhana berupa review bersama dengan guru dan yang membutuhkan persiapan khusus melalui kegiatan SLC mengkomunikasikan semua yang telah dipelajari di depan orangtua.

Jadi, kesimpulan untuk kemunculan pengalaman pokok belajar (5M) dalam pelaksanaan pendekatan scientific untuk ketiga subjek penelitian disajikan dalam tabel berikut:

Tabel.1. Kemunculan Komponen 5M dalam Pelaksanaan Pendekatan Scientific untuk Ketiga Subjek

\begin{tabular}{ccccc}
\hline No & $\begin{array}{c}\text { Lima pengalaman pokok belajar } \\
\text { dalam pendekatan Scientific }\end{array}$ & S-T & Subjek & S-S \\
\cline { 3 - 5 } & Mengamati & Muncul & Muncul & Muncul \\
\hline 1 & Menanya & Muncul & Muncul & Muncul \\
\hline 3 & $\begin{array}{c}\text { Mencoba/mengumpulkan } \\
\text { data/mengumpulkan informasi }\end{array}$ & Muncul & Muncul & Muncul \\
\hline 4 & Menalar/mengasosiasi/mengolah & Muncul & Muncul & $\begin{array}{c}\text { Tidak } \\
\text { Muncul }\end{array}$ \\
\hline 5 & Mengomunikasikan & $\begin{array}{c}\text { Tidak } \\
\text { Muncul }\end{array}$ & $\begin{array}{c}\text { Tidak } \\
\text { Muncul }\end{array}$ & $\begin{array}{c}\text { Tidak } \\
\text { Muncul }\end{array}$ \\
\hline
\end{tabular}


Berdasarkan Tabel.1 terlihat masih ada komponen yang belum muncul pada setiap subjek. Terutama untuk komponen mengkomunikasikan pada setiap subjek, deskripsi kegiatan yang muncul tidak memenuhi indikator yang telah ditetapkan. Hal ini tentu belum sesuai dengan harapan kurikulum 2013 yang menekankan proses pembelajaran dapat terlaksana sesuai harapan dengan menggunakan komponen 5M.

\section{KESIMPULAN}

Berdasarkan deskripsi kegiatan siswa selama proses pembelajaran berlangsung, dapat disimpulkan masih terdapat deskripsi kegiatan siswa yang belum termasuk kedalam komponen pendekatan scientific. Komponen yang belum terlihat yaitu komponen mengkomunikasikan. Mengkomunikasikan yang diharapkan dalam pembelajaran dengan pendekatan scientific ini adalah menyajikan laporan dalam bentuk bagan,diagram, atau grafik; menyusun laporan tertulis; dan menyajikan laporan meliputi proses, hasil, dan kesimpulan secara lisan. Namun kenyatannya dalam pembelajaran yang berlangsung hanya sebatas mengkomunikasikan sesama teman sekelompok saja. Presentasi ataupun memaparkan ide-ide secara lisan belum muncul dalam pembelajaran.

\section{REFERENCES}

Arifin, Z. (2013). Konsep dan Model Pengembangan Kurikulum, Bandung: Remaja Rosdakarya.

Astuti, L.D. (2016). Analisis Pelaksanaan Pembelajaran Matematika Materi Transformasi dengan Pendekatan Scientific Kurikulum 2013. Skripsi. Yogyakarta: Universitas Sanata Dharma

Atsnan, M.F. \& Gazali, R. Y. (2013). Penerapan Pendekatan Scientific dalam Pembelajaran Matematika SMP Kelas VII Materi Bilangan (pecahan). Makalah dipresentasikan dalam Seminar Nasional Matematika dan Pendidikan Matematika pada tanggal 9 November 2013 di Jurusan Pendidikan Matematika FMIPA UNY. 978-979.

Dewi. A.,\& Mukminan, M. (2016). Implementasi Pendekatan Saintifik dalam Pembelajaran IPS di Middle Grade SD Tumbuh 3 Kota Yogyakarta. Jurnal prima edukasia, 4(1), 20 - 31.

Fauziah, R. et al. (2013). Pembelajaran Saintifik Elektronika Dasar Berorientasi Pembelajaran Berbasis Masalah. Jurnal Invotec, 9(2): 165-178.

Kementrian Pendidikan dan Kebudayaan. (2013c). Salinan Permendikbud No. 65, tentang Standar Proses.

Hosnan. (2014). Pendekatan Saintifik dan Konstektual dalam Pembelajaran Abad 21 Kunci Sukses Implementasi Kurikulum 2013. Bogor: Ghalia Indonesia.

Kementrian Pendidikan dan Kebudayaan. (2013d). Salinan Permendikbud No. 81 A Lampiran Empat, tentang Pedoman Umum Pembelajaran.

Kunandar. (2013). Penilaian Autentik (Penilaian Hasil Belajar Peserta Didik Berdasarkan Kurikulum 2013). Edisi Pertama. Jakarta: Raja Grafindo Persada. 
Maprokhi (2015). Pengembangan Perangkat Pembelajaran Matematika SMP Kelas VIII Semester Genap dengan Pendekatan Saintifik. Jurnal Pendidikan Matematika, 10(2) 168-178.

Prasetio, B. \& Santosa, H. R. (2015). Pengembangan Perangkat Pembelajaran Matematika untuk SMP Kelas VII Semester Genap dengan Pendekatan Saintifik. Jurnal Pendidikan Matematika, 10(2) 117-128.

Rusindrayanti \& Santosa, H. R. (2015). Implementasi Pendekatan Saintifik Mapel Matematika Kelas VII Tahun Pelajaran 2013/2014 pada Kurikulum 2013 DIY. Jurnal Pendidikan Matematika, 10(1) 80-94.

Santi, K.L,. \& Santosa, H. R. (2016). Pengembangan Perangkat Pembelajaran Menggunakan Pendekatan Saintifik pada Materi Pokok Geometri Ruang SMP. Jurnal Pendidikan Matematika, 11(1) 35-44.

Sariono. (2014). Kurikulum 2013: Kurikulum Generasi Emas. E-Jurnal Dinas Pendidikan Kota Surabaya, Vol 3, 2337-3252.

Surachman., Wibowo, Y.,\& Suhardi. (2014). Implementasi Scientific Process pada Mata Pelajaran Biologi di MA Kotamadya Yogyakarta. Jurnal Pendidikan Matematika dan Sains, Tahun II, Vol 2, Desember 2014. 